\title{
Effects of habitat fragmentation on the persistence of medium and large mammal species in the Brazilian Savanna of Goiás State
}

\author{
Ednaldo Cândido Rocha ${ }^{I}{ }^{\mathbb{D}}$, Daniel Brito ${ }^{2}$, Paulo Machado e Silva ${ }^{3}$, Jhefferson Silva ${ }^{1}$, \\ Paulo Vitor dos Santos Bernardo ${ }^{2}$ \& Leandro Juen ${ }^{4}$ \\ ${ }^{1}$ Universidade Estadual de Goiás, Câmpus de Ipameri, Rodovia GO 330, km 241, Anel Viário, CEP 75780-000, \\ Ipameri, GO, Brasil. \\ ${ }^{2}$ Universidade Federal de Goiás, Instituto de Ciências Biológicas, CEP 74001-970, Goiânia, GO, Brasil. \\ ${ }^{3}$ Consultor Ambiental, Rua Vereador Luiz de Oliveira, 4, Centro, CEP 75780-000, Ipameri, GO, Brasil. \\ ${ }^{4}$ Universidade Federal do Pará, Laboratório de Ecologia e Conservação, Instituto de Ciências Biológicas, \\ Rua Augusto Correia, $n^{\circ}$ 1, Bairro Guamá, CEP: 66075-110, Belém, PA, Brasil. \\ *Corresponding author: Ednaldo Cândido Rocha, e-mail: ednaldo.rocha@ueg.br
}

ROCHA, E.C., BRITO, D., SILVA, P.M., SILVA, J., BERNARDO, P.V.S, JUEN, L. Effects of habitat fragmentation on the persistence of medium and large mammal species in the Brazilian Savanna of Goiás State. Biota Neotropica. 18(3): e20170483. http://dx.doi.org/10.1590/1676-0611-BN-2017-0483

\begin{abstract}
Habitat loss and fragmentation are the main threats to the conservation of Cerrado biodiversity. The objective of this study was to evaluate the implications of habitat loss on the persistence of medium and large mammal species, considering the spatial and temporal changes (years 1985, 2000 and 2014) to the evaluated fragments. The study was carried out in 14 fragments $(10.5-618$ ha), located in Southeastern Goiás, Brazil. Records for 24 mammal species were obtained and revealed the two sites with the largest habitat amount in the landscape contained higher species richness than the remaining sites. The three mammal groups based on body mass (weight $<5 \mathrm{~kg}$; weight between 5 and $20 \mathrm{~kg}$; and weight $>20 \mathrm{~kg}$ ) analyzed in this study showed different responses regarding landscape changes. For larger mammals (between $5-20 \mathrm{~kg}$ and $>20 \mathrm{~kg}$ ), there was significant association between current species richness and the amount of habitat in 2014, while the species richness of smaller mammals did not significantly correlate with any of the variables assessed for any of the years. Therefore, the amount of habitat present within the current landscape was the most important variable regarding mammal species richness, especially for the larger species. The time lag was not evident at the time scale evaluated, and this delay in response may have occurred in a relatively short time $(<15$ years). For the remaining fragments in the studied landscapes, most are too small to support populations of some larger mammal species and may also leave individuals more vulnerable to anthropogenic actions (e.g. hunting), whose effects may accelerate local extinctions. Keywords: Biodiversity conservation, Landscape ecology, Mammal fauna, Species richness.
\end{abstract}

\section{Efeitos da fragmentação de habitat na persistência de espécies de mamíferos de médio e grande porte no Cerrado em Goiás}

Resumo: A perda e a fragmentação de habitats são as principais ameaças à conservação da biodiversidade no bioma Cerrado. O presente estudo objetivou avaliar as implicações da perda de habitat na persistência de espécies de mamíferos de médio e grande porte, levando em consideração as alterações espaciais e temporais dos fragmentos avaliados. O estudo foi realizado em 14 fragmentos (10,5 - 618 ha), localizados na região sudeste de Goiás, Brasil. Foram obtidos registros de 24 espécies de mamíferos, sendo que os dois locais com as maiores quantidades de habitat na paisagem apresentaram maior riqueza de espécies que as demais áreas. Os três grupos de mamíferos baseados na massa corporal criados neste estudo (peso $<5 \mathrm{~kg}$; peso entre 5 e $20 \mathrm{~kg}$; e peso $>20 \mathrm{~kg}$ ) apresentaram respostas diferentes em relação às mudanças na paisagem. Para os mamíferos de maior porte, houve significativa associação entre a riqueza atual de espécies e a quantidade de habitat na paisagem de 2014, mas a riqueza de espécies de mamíferos de menor porte não apresentou relação significativa com nenhuma das variáveis das paisagens analisadas. Portanto, a quantidade de habitat presente na paisagem atual foi a variável mais importante para a riqueza de espécies de mamíferos, principalmente para as espécies de maior porte. $\mathrm{O}$ tempo de latência não ficou evidente na escala temporal avaliada, sendo que esse atraso na resposta pode ter ocorrido em tempo relativamente curto ( $<15$ anos), pois os fragmentos remanescentes nas paisagens estudadas em sua maioria são pequenos para suportar populações de mamíferos de maior porte e também podem deixar os indivíduos mais vulneráveis às ações antrópicas (e.g. caça), cujos efeitos podem acelerar as extinções locais.

Palavras-chave: Conservação da biodiversidade, Ecologia de paisagem, Mastofauna, Riqueza de espécies. 


\section{Introduction}

Natural preserved areas have decreased due to human activities and become restricted in tropical regions (Laurance et al. 2014). Expanding agriculture, pasture and increasing human population density are some of the causes responsible for the reduction of natural areas. The region of Central Brazil is subject to intensive agricultural activities which contribute to natural habitat loss. The Brazilian savanna (nationally known as the Cerrado biome) originally occupied approximately 2 million $\mathrm{km}^{2}$ of Central Brazil (approximately 23\% of the country's territory), with vegetation physiognomy that includes forests, savannas and grasslands (Ribeiro \& Walter 1998). This biome was included as one of the planet's 34 hotspots due to its highly endemic biodiversity and threatened status (Myers et al. 2000, Mittermeier et al. 2005). Over the past five decades, the Brazilian savanna has experienced a rapid reduction in original vegetation cover due to the expansion of the agricultural frontier in central Brazil.

Estimates indicate that approximately half of the original Brazilian savanna coverage has been transformed into planted pastures, annual crops and other types of land use (Ratter et al. 1997, Klink \& Machado 2005). This marked expansion of socio-economic activity has contributed to the large-scale landscape change of the Brazilian savanna, resulting in many highly fragmented areas (Sano et al. 2007, Carvalho et al. 2009). These processes of habitat loss and fragmentation have been identified as the main threats to biodiversity (Ahumada et al. 2011, Gibson et al. 2011).

Habitat fragmentation can be defined as a process through which a continuous habitat is transformed into "small habitat pieces", with the disconnection of a previously continuous area (Pires et al. 2006, Carvalho et al. 2009). Habitat fragmentation processes include landscape changes such as habitat loss, reduction in habitat patch size, connectivity alteration, increased edge effects and increased matrix area (Uezu et al. 2005, Michalski \& Peres 2007, Norris \& Peres 2008). The quantification of landscape variables has assumed a preeminent role in landscape ecology (MacGarigal \& Ene 2013), providing a measure of fragmentation (Carvalho et al. 2009). The alterations in these landscape variables cause changes in local biodiversity at both the population level - such as changes in the number, distribution, reproduction, survival and recruitment of individuals (Wolff et al. 1997, Fahrig 2003), and at the community level, with changes in species composition and richness (Chiarello 1999, Santos-Filho et al. 2012). Fahrig (2003) points out that negative fragmentation effects arise from two main causes: 1) habitat fragmentation products are smaller fragments than the original; these small fragments generally do not possess sufficient habitat area to support most of the species, or even for one individual. In this way, the persistence of most species, especially those sensitive to matrix, are confined to fragments; 2) the level of fragmentation in a landscape is positively related to the amount of edge effects in that landscape. This may increase the probability of the most sensitive and specialized species leaving the habitat fragment in search of more suitable areas, which can lead to increased mortality rates and reduced reproductive rates of the population if environments with favorable conditions are not found (Fahrig 2003). Additionally, the introduction of new forms of land use in place of the original vegetation can cause negative alterations in environmental heterogeneity and consequently, in the resource supply for the species (Lion et al. 2016), because it leads to greater homogeneity.
Several changes in biodiversity can be observed within a short period of time following changes in landscape structure, however some species decline and disappear only after prolonged periods of time (Kuussaari et al. 2009). The number of species expected to eventually become extinct as the community reaches a new equilibrium after environmental disturbance, also called extinction debt, is an important factor to be considered in biodiversity conservation (Kuussaari et al. 2009, Krauss et al. 2010). Extinction debt can be assumed when the past characteristics of a particular landscape explain the current species richness and composition better than current landscape characteristics (Kuussaari et al. 2009, Krauss et al. 2010). The likelihood and magnitude of extinction debt depend on the species' life history (e.g. dispersion capacity, reproductive rates, habitat demands), the spatial and temporal configuration of the habitat fragment, the time since the habitat was changed and the nature of the change (Kuussaari et al. 2009). The local group of specialist species finds a new balance point after the disturbance, which may take some time for those with a long life cycle (Krauss et al. 2010). Therefore, many of the management and conservation strategies adopted today may not be effective, as the delay in response to landscape alterations is not taken into consideration.

Different mammal taxa should be affected in different ways as a consequence of environmental change. As a result, the different mammal groups (based on body mass) should exhibit different responses to habitat fragmentation (Keinath et al. 2018). Mammals with large home ranges and longer life cycles are usually more sensitive than those with smaller home ranges and shorter life cycles (Morris et al. 2008). They need more resources and energy than smaller mammals to complete their life cycles and live in low densities and are exploited by humans (Cardilho et al. 2005). Therefore, conservation strategies consider mammals with a larger body mass as umbrella species, as protecting these species provides the indirect conservation of other species within the area.

Delayed response is still largely unexplored in researches investigating the effects of natural habitat change on species, especially in Brazil. Researches on extinction debt carried out so far have primarily evaluated plants and birds, whereas mammals have rarely been the object of study (Semper-Pascual et al. 2018). Thus, the objective of this study was to assess the implications of habitat loss on the persistence of medium and large mammal species, considering the spatial and temporal changes in the evaluated landscapes. We tested the hypothesis that fragmentation processes occurring within landscapes negatively affect mammalian species richness, with those effects felt for long periods of time, leading to the local extinction of some species, particularly larger mammals. Such information may help reduce the knowledge gap on the long-term effects of fragmentation on medium and large mammal species richness.

\section{Materials and Methods}

\section{Mammal study areas and data}

The areas studied are located in southeastern Goiás (Brazil), comprised of Brazilian savanna and include some places considered Atlantic forest enclaves (Felfili 2003). The climate is classified as Aw (tropical seasonal) with annual rainfall of approximately $1600 \mathrm{~mm}$ and 
is characterized by two distinct seasons, a dry winter and rainy summer, with temperatures averaging around $23^{\circ} \mathrm{C}$ (Alvares et al. 2014).

Data collection was conducted in two different methods: 1) secondary data surveys; and 2) primary data surveys in the field. By combining these methods, information was obtained from 14 savanna fragments located in southeastern Goiás (Figure 1). Recent studies carried out in the southeast of Goiás were used as secondary data sources on medium and large mammals, namely the mammal inventory of Parque Estadual Mata Atlântica - PEMA, Água Limpa municipality (Rocha et al. 2015). The secondary data was incorporated as it was derived from one of the largest protected areas in the region (PEMA), and could serve as a control for species richness. In addition, the data was collected ( $\mathrm{n}=16$ days of sampling effort) during 2012 and 2013, the same period in which sampling took place at other locations. Thirteen Savanna fragments of different shapes and sizes were selected for field data collection (Appendix I). These habitat patches were situated in private properties containing native vegetation, with sampling sites located at areas of permanent protection along riverbanks and adjacent legal reserves. Fragments were chosen with the aid of satellite imagery, and areas were selected in the municipalities of Ipameri $(n=10)$, Catalão $(\mathrm{n}=2)$ and Urutaí $(\mathrm{n}=1)$.

Collection of field data was carried out between May 2011 and October 2014, with the 13 chosen fragments sampled four times each through direct (visual and vocal) and indirect (tracks, burrows and other signs) methods for recording mammal species. This sampling effort totalled 52 days of field data collection. Each fragment was randomly inspected. Roads, previously existing trails and riverbanks were searched for traces of mammal species. In addition, a camera trap was installed to complement the species inventory, with a total sampling effort of 72 traps*night.

Only mammal species that depend on the forest and dense savanna environment as an important habitat resource were included in this study, as alterations in this kind of habitat present in the landscape were evaluated. We used Reis et al. (2006) for this classification. Therefore, although they were recorded during field surveys, the species that prefer open habitats [e.g. hoary fox Lycalopex vetulus (Lund, 1842) and maned-wolf Chrysocyon brachyurus (Illiger, 1815)] and semi-aquatic habitat species [water opossum Chironectes minimus (Zimmermann, 1780), otter Lontra longicaudis (Olfers, 1818) and Hydrochoerus hydrochaeris (Linnaeus, 1766)] were not included. Furthermore, species groups based on body mass were created in order to assess whether effect of fragmentation change between mammals with different sizes classes. Average animal weights from Paglia et al. (2012) were used. Mammals were divided into three groups: 1 - less than $5 \mathrm{~kg}(\mathrm{n}=9$ species); 2 - between 5 and $20 \mathrm{~kg}(\mathrm{n}=9$ species); and 3 - greater than $20 \mathrm{~kg}(\mathrm{n}=7$ species $)$.

\section{Landscape data}

Analysis of the landscape was carried out using land use maps obtained from visual satellite imagery classification. Landsat 5 satellite images from 1985, 2000 and 2014 provided by the National Institute for Space Research (INPE) were used. Two land use classes were visually created in the mapping: 1) habitat - forests and/or non-open savanna areas that were at least two pixels wide $(60 \mathrm{~m}) ; 2$ ) non-habitat - matrix with altered original vegetation, pastures, lakes, rivers and open savanna areas (open shrubland and grassland).
To analyze the structure of the landscape, buffers were created with a 2-km radius from the center of each sampled area (Krauss et al. 2010). In a study that tested various scales, Lyra-Jorge et al. (2009) found a greater association between landscape and carnivore species at the highest scale assessed (buffer with 2-km radius). Furthermore, the chosen scale did not allow buffer overlapping, which avoided spatial autocorrelation. Based on the classified maps, landscape variables were generated [habitat amount (HA), number of habitat patches (NP), total edge (TE), largest patch index (LPI), landscape shape index (LSI), mean patch area (AREA_MN), contiguity index (CONTIG), total core area (TCA), mean Euclidean distance of nearest neighbors (ENN_MN), clumpiness index (CLUMPY) and splitting index (SPLIT)] for each year evaluated (1985, 2000 and 2014) using Fragstats 4.2 software (MacGarigal \& Ene 2013). These variables, which are associated with all patches of habitat present in the landscape and measure the quantity and the spatial configuration of each patch, were used as measures of fragmentation (Carvalho et al. 2009, MacGarigal \& Ene 2013).

\section{Data analysis}

Landscape variables generated for the years 1985, 2000 and 2014 were subjected to Principal Component Analysis (PCA) in order to reduce data dimensionality and indicate the selection of those which were less correlated. The data was standardized for analyses, with a covariance matrix then used. Broken Stick criterion was used to select axes. From the PCA results, three variables were selected as the main landscape characteristics: the habitat amount (HA), number of habitat patches within the landscape (NP), and average Euclidean distance of nearest neighbors in the landscape (ENN_MN). A Permutational Multivariate Analysis of Variance - PERMANOVA (Anderson 2001), using Euclidian Distance as a dissimilarity measure, and a post-hoc Dunn's test was applied to test if there was a difference in landscape structure between analyzed years. Association between mammal species richness and landscape characteristics, past and present, was tested by way of multiple regression analysis with a selection model (forward stepwise) used to select the best models. Statistical analyses were done in R program ( $\mathrm{R}$ Development Core Team 2017), using the 'vegan' package (Oksanen et al. 2017).

\section{Results}

Landscape variables pointed to a significant change in landscape structure between 1985 and 2014 (Pseudo $F=2.70 ; p=0.03$ ). The average size of habitat patch (HA) within buffers was gradually reduced [year $1985($ mean $=477$ ha, range $=144-943)$; year $2000($ mean $=397$ ha, range $=165-741)$; year $2014($ mean $=318$ ha, range $=97-815)$, while the average number of habitat patches (NP) increased from 2000 to 2014 [year 1985 (mean $=11.9$, range $=3-23)$; year 2000 (mean $=10.4$, range $=4-18)$; year $2014($ mean $=18.8$, range $=5-30)$ ], and average Euclidean Distance of the nearest neighbors within the landscape (ENN_MN) increased from 1985 to 2000 and then has small reduction [year 1985 (mean $=156 \mathrm{~m}$, range $=75-275)$; year 2000 $($ mean $=192 \mathrm{~m}$, range $=114-293)$; year $2014($ mean $=173 \mathrm{~m}$, range $=78-368)$ ] (Figures 2 and 3 ). The changes in these variables reveal the progress of fragmentation during this period, with the average percentage of habitat area within buffers reduced from approximately $38 \%$ in 1985 to $32 \%$ in 2000 and $25 \%$ in 2014 (Figure 3). 


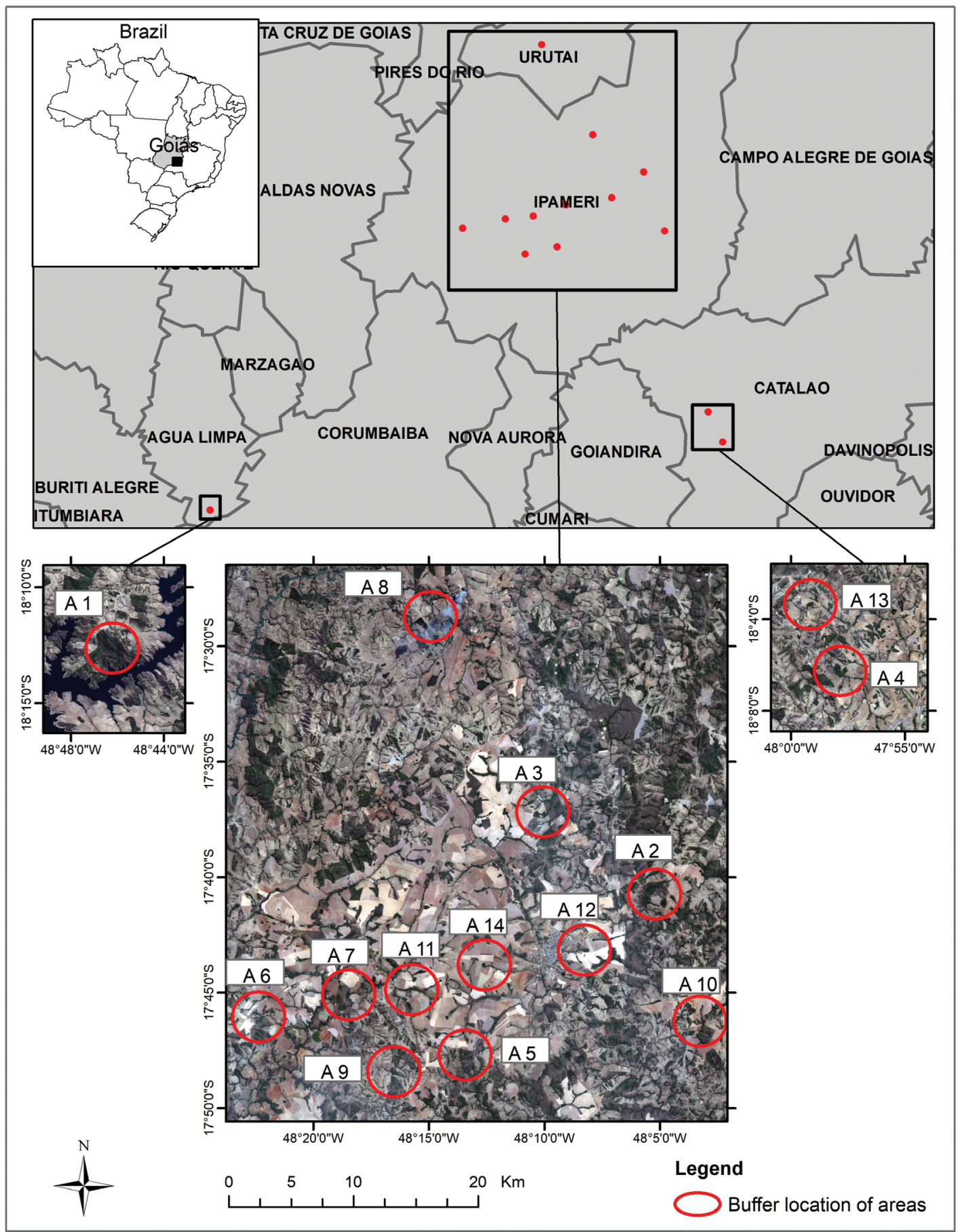

Figure 1. Location of the 14 fragments sampled in southeastern Goiás. Red circles represent the landscapes delimited with a radius of $2 \mathrm{~km}$ from the center of each fragment studied.

Records were obtained for 24 mammal species from eight orders that use the forest environment: Didelphimorphia (one species), Pilosa (two species), Cingulata (four species), Perissodactyla (one species) Artiodactyla (three species), Primates (three species), Carnivora (eight species) and Rodentia (two species) (Appendix II). Species were identified primarily by their tracks, but also by sightings, burrows, feces and camera trap. Among the recorded species, five are classified as endangered in Brazil (MMA 2014): Giant Anteater Myrmecophaga tridactyla (Linnaeus, 1758), Giant Armadillo Priodontes maximus (Kerr, 1792), Tapir Tapirus terrestris (Linnaeus, 1758), Puma Puma concolor (Linnaeus, 1771), and Jaguarundi Puma yagouaroundi (É. Geoffroy, 1803). Under IUCN criteria (IUCN 2017), the Giant Anteater, Giant Armadillo and Tapir are classified as vulnerable; the South American Red Brocket Mazama Americana (Erxleben, 1977) and Azara's Agouti Dasyprocta azarae Lichtenstein, 1823 are classified as data deficient; and the remaining species are classified as least concern. 


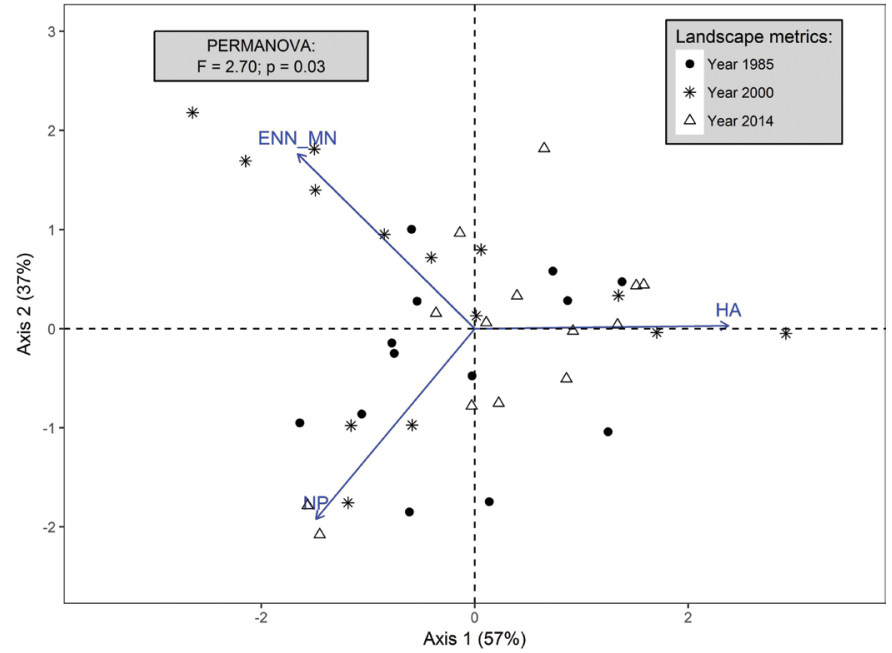

Figure 2. Principal Component Analysis (PCA) and Permutational Multivariate Analysis of Variance (PERMANOVA) of landscape variables (habitat amount (HA, in hectares); number of habitat patch (NP, without unity); and average Euclidean distance of nearest neighbors (ENN_MN, in meters), with data from the 14 fragments in southeastern Goiás.
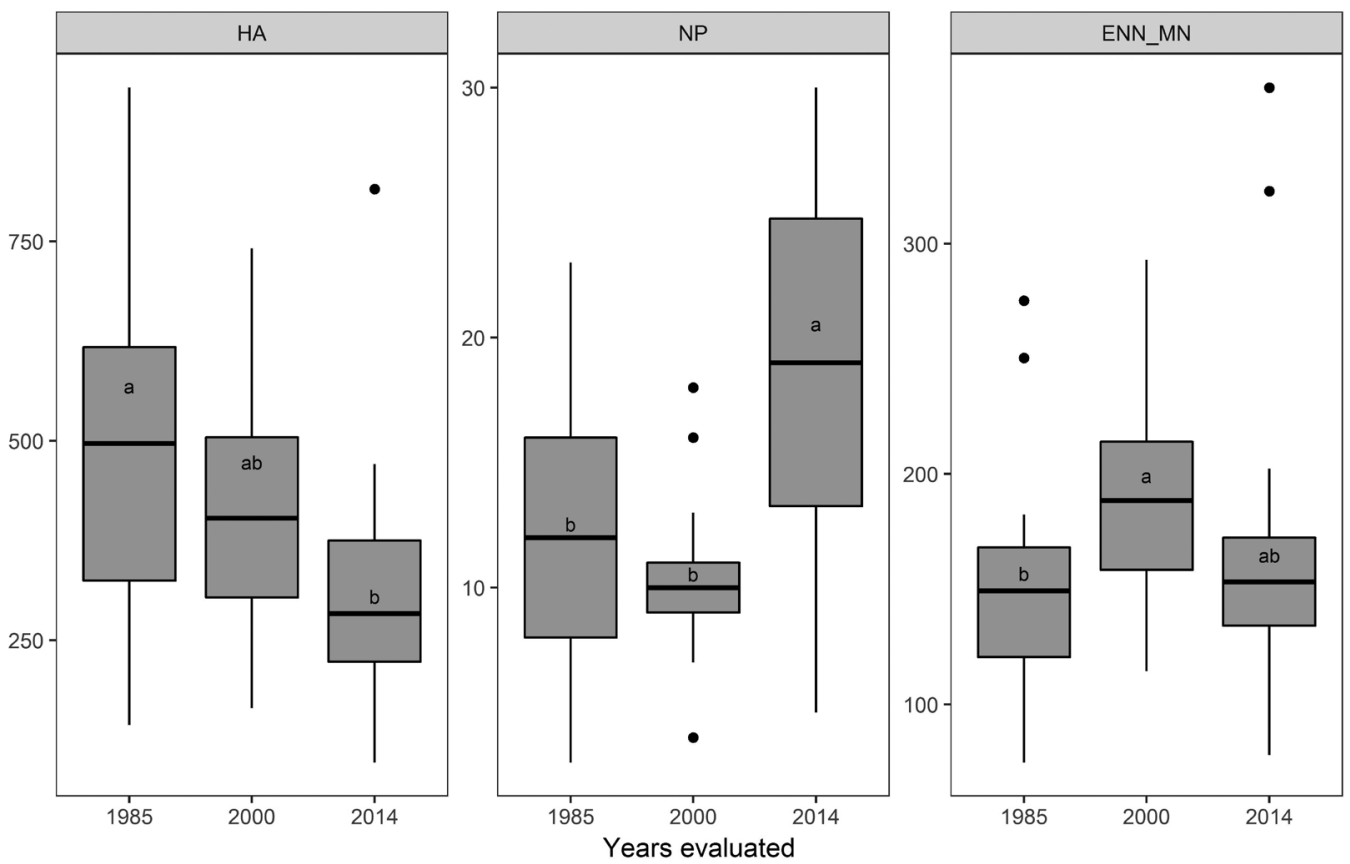

Figure 3. Box plot for the landscape variables analyzed [habitat amount (HA, in hectares); number of habitat patch (NP, without unity); and average Euclidean distance of nearest neighbors (ENN_MN, in meters)], with data from the 14 fragments in southeastern Goiás. For each variable, annual values accompanied by distinct letters differ by the Dunn's test ( $\mathrm{p}<0.05)$.

The multiple regression model adjusted for all recorded mammal species indicated that landscape characteristics affected the actual species richness $\left(\mathrm{F}_{(3 ; 10)}=11.62 ; \mathrm{p}=0.001\right.$; adjusted $\left.\mathrm{R}^{2}=0.71\right)$. The partial coefficients indicated that only total habitat area within the landscape (HA) for 2014 presented a significant effect $(p=0.001)$ on total species richness (Table 1), showing a positive relationship with the current mammal species richness.

The mammal groups created in this study based on body mass presented different responses to landscape change. Multiple regression models pointed to a significant effect of landscape characteristics on the species richness of mammals with body mass between 5 to $20 \mathrm{~kg}\left(\mathrm{~F}_{(3 ; 10)}=5.402 ; \mathrm{p}=0.018\right.$; adjusted $\left.\mathrm{R}^{2}=0.504\right)$ and species weighing over $20 \mathrm{~kg}\left(\mathrm{~F}_{(3 ; 10)}=5.400 ; \mathrm{p}=0.018\right.$; adjusted $\left.\mathrm{R}^{2}=0.504\right)$. For the species group with an intermediary body mass (5 to $20 \mathrm{~kg}$ ), the variable HA for the year 2014 (positive effect) and the number of habitat patches within the landscape (NP) for the year 2000 (negative effect) exhibited a significant effect for partial coefficients $(p=0.026$ and 0.047 , respectively). For the species group with a larger body mass 
Rocha, E.C. et al.

Table 1. Coefficients of multiple regression evaluating the relationship between mammal species richness and landscape variables in 14 fragments in southeastern Goiás.

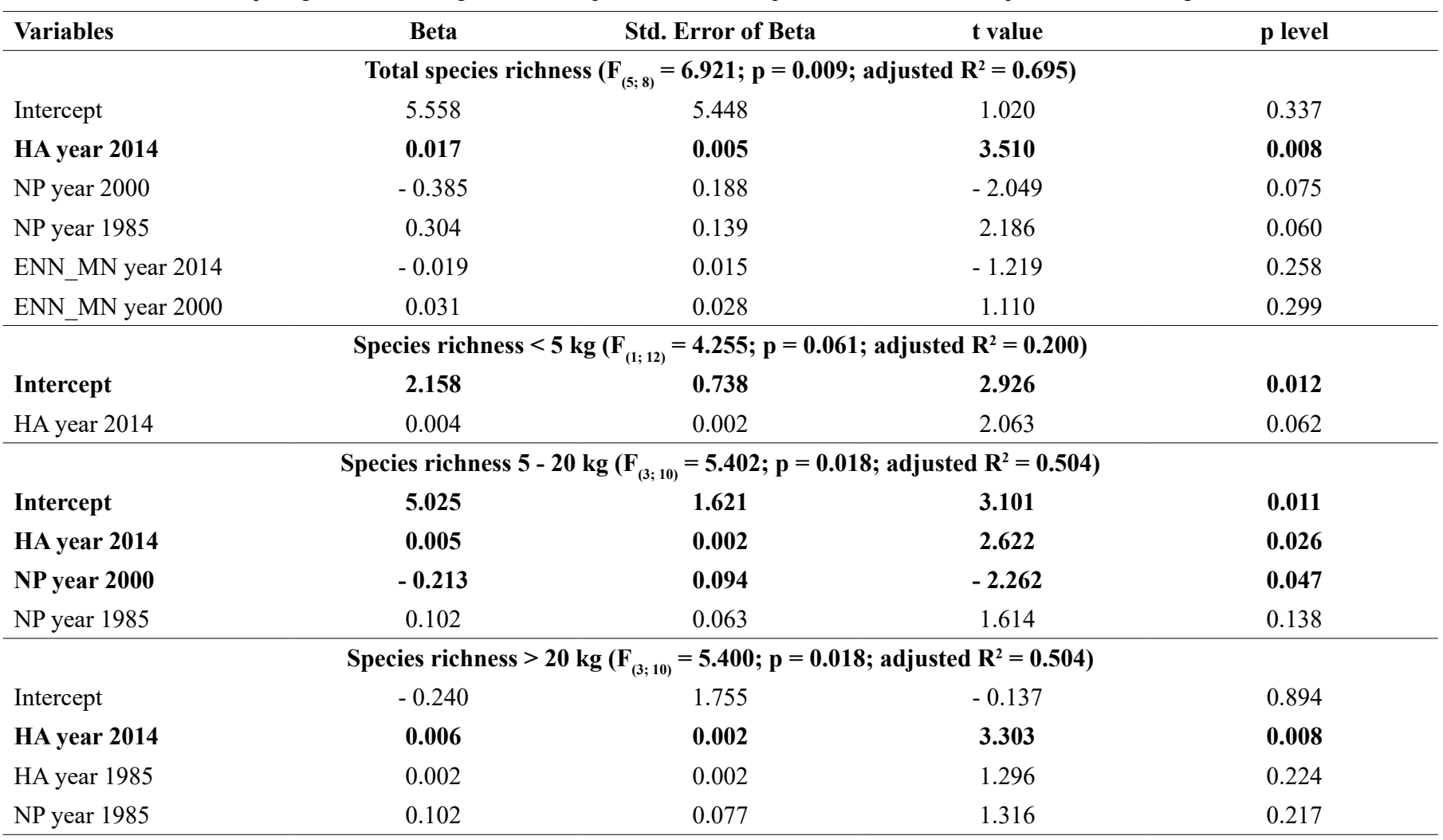

(>20 kg), only the variable HA for the year 2014 indicated a positive and significant effect for partial coefficients $(\mathrm{p}=0.008)$ and correlation analysis $(\mathrm{r}=0.56 ; \mathrm{p}=0.037)($ Table 1$)$.

\section{Discussion}

The landscape alterations analyzed in this study highlighted an increase in fragmentation and a reduction of native vegetation in this region of the Brazilian savanna during the period 1985 to 2014 (Ratter et al. 1997, Carvalho et al. 2009). The species richness of medium and large mammals recorded in the studied fragments shows the importance of Parque Estadual Mata Atlântica and the fragments on private property in Southeast Goiás for the region's in situ conservation of mammals. These areas are situated within a highly fragmented landscape where there are very few large areas of native vegetation that can serve as a safeguard for wildlife. By comparison with nearby areas: Alves et al. (2014) recorded 18 species of mammals in three fragments in Uberlândia, state of Minas Gerais; Estrela et al. (2015) recorded 25 species of mammals in a fragment in the municipality of Urutaí, state of Goiás.

Overall, the areas with the largest habitat amount (HA) within the landscape showed greater mammal species richness than areas with less habitat amount, which shows the importance of areas with greater habitat extent in the conservation of this fauna group. This result supports the habitat amount hypothesis presented by Fahrig (2013), who argues that total habitat in the landscape (HA) is the variable with the greatest influence on species richness. The trend of increasing species richness in parallel with increasing forest fragment size was found in studies with medium and large-sized mammals in Atlantic Forest areas in Espírito Santo State (Chiarello 1999) and Southern
Brazilian Amazonia (Michalski \& Peres 2007). Furthermore, while studying small non-flying mammals in 23 fragments of the Southern Amazon, Santos-Filho et al. (2012) also observed a positive correlation between fragment size and species richness. Among the measurable landscape variables in habitat fragmentation, habitat reduction has the greatest effect on biodiversity (Fahrig 2003, 2013), with this effect mostly in a negative form.

The importance of landscape variables on mammal species richness varied according to the size class considered. In our study it was important only for classes above five kilograms, particularly HA for the year 2014, which stood out above the other variables. To understand the reasons behind different responses between mammal groups, it is necessary to take into account the landscape variables as well as the life history of the animals that make up each group (Kuussaari et al. 2009). In general, smaller mammals have less mobility and need less habitat when compared to larger mammals. Furthermore, they tend to have shorter life cycles and possibly a more rapid response to environmental changes (Morris et al. 2008). A response delay was not detected in the evaluated time scale. Similarly, Metzger et al. (2009) did not found extinction debt for small mammals in the Atlântic Forest. In this sense, studies with short-life-cycle animals (such as butterflies) have shown that the current landscape explains species richness better than the former landscape, indicating short time response. Lindborg (2007) observed that short-life-cycle plants were positively correlated with the current characteristics of the landscape, while long-life-cycle plants were more associated with historical landscape characteristics. Some studies have identified extinction debt in plants occurring between 40 and 160 years after environmental perturbation, depending on the degree of fragmentation and connectivity (Cousins \& Vanhoenacker 2011). 
For larger mammals in this study $(>5 \mathrm{~kg})$, there are indications that extinction debt is occurring in short period $(<15$ years after alterations to the landscape), given the association between recent landscape characteristics and current species richness, especially regarding the habitat amount within the landscape (HA) in 2014. In a study carried out in Argentine Dry Chaco, Semper-Pacual et al. (2018) found relaxation time (the time needed to reach a new equilibrium) ranging from 10 to 25 years for medium and large-bodied mammals. Detecting extinction debt may not be easy, as the length of time for extinction occurrence depends on the local ecosystem, the species group studied - due to species-specific time-lags that are affected by generation time and reproductive rate, the extent and pattern of fragmentation (Claudino et al. 2015, Kolk \& Naaf 2015) and on the evaluated spatial scale (Cousins \& Vanhoenacker 2011). Furthermore, the effects of hunting on mammals can influence local species extinction, particularly larger animals and those in smaller fragments (Chiarello 1999, Peres 2000). This effect is detected and shown to be important in other studies (Cullen Jr. et al. 2000, Peres 2000). Isolated populations are often more accessible to both natural and human predators and these factors tend to alter the resilience of species to hunting and amplify the impact of hunting in small and isolated fragments (Cullen Jr. et al. 2000).

Local mammal extinctions can be seen in this study when noticing that in any of the sampled areas records were obtained of some species that are present in large areas of Brazilian savanna in Goiás state, such as the Jaguar Panthera onca (Linnaeus, 1758) and the Peccary Tayassu peccary (Link, 1795) recorded in Emas National Park (Rodrigues et al. 2002). In this sense, landscapes with less habitat (HA) are not sufficient to support populations of large predators (e.g. big cats) and, in the absence of these apex predators, species richness may also decrease due to the strong competition between their prey and the increase in mesopredator abundance (Crooks \& Soule 1999, Prugh et al. 2009). The presence of Tapir Tapirus terrestris (Linnaeus, 1758) in only one area (A1) and South American Red Brocket Mazama americana (Erxleben, 1777) in another (A2), which are currently the two sites with the largest habitat amount (HA) within buffers, indicates that these species are already extinct in places with smaller areas of forest habitat. In one of the studied fragments (A14), old Giant Armadillo Priodontes maximus (Kerr, 1792) burrows were found, however no recent records of this species have been obtained, suggesting the local and relatively recent extinction in this area. By comparison, in a study carried out in Atlantic forest fragments in the state of Espírito Santo, Brazil, Chiarello (1999) did not obtain any records of big cats, peccaries, Giant Armadillos or Anteaters Myrmecophaga tridactyla Linnaeus, 1758 in small fragments (e.g. less than 200 ha).

Our results allow us to substantiate the hypothesis that fragmentation processes in Southeast Goiás negatively affect mammal species richness, mainly for those with a larger body mass. Habitat amount (HA) of the current landscape affecting the richness of mammalian species more strongly than the other variables tested (Table 1). Although these results have not shown the exact amount of time to local disappearance of medium and large mammals due to habitat loss, they confirm that the amount of habitat is crucial for the persistence of mammals, especially for larger species.

It should be noted that the strategies for management and conservation of mammal species in fragmented locations based solely on the current habitat situation may not be effective for all mammal species. In our study, the time lag was not evident at the time scale evaluated, and this delay in response may have occurred in a relatively short time $(<15$ years $)$. For the remaining habitat patches in the studied landscapes, most are too small to support populations of some larger mammal species and may also leave individuals more vulnerable to anthropogenic actions (e.g. hunting), whose effects may accelerate local extinctions.

\section{Supplementary material}

Appendix I- Information on the 14 sampled fragments in the state of Goiás, Brazil.

Append1x II- Mammal species recorded in 14 fragments in southeastern Goiás. See more details on sampled areas in Appendix I.

\section{Acknowledgments}

We thank the people and institutions who have contributed directly or indirectly to the execution of this study, especially: the Fundação de Amparo à Pesquisa do Estado Goiás (FAPEG) and the Coordenação de Aperfeiçoamento de Pessoal de Nível Superior (CAPES) for the granting of a post-doctoral scholarship and for funding the translation (AUXPE-FAPEG 2370/2014); we also thank the Goiás State University (UEG) for research fellowships ECR (PROBIP/PrP 009/2016) and Conselho Nacional de Desenvolvimento Científico e Tecnológico (CNPq) by LJ (process 307597/2016-4) and by DB.

\section{Author Contributions}

Ednaldo Cândido Rocha: concept and design of the study, performed collection of field data, and carried out the data analysis and wrote the paper.

Daniel Brito: contribution in the concept and design of the study, critical revision, and adding intellectual content.

Paulo Machado e Silva and Jhefferson Silva: performed collection of field data, and the data analysis.

Paulo Vitor dos Santos Bernardo and Leandro Juen: contribution in the data analysis, critical revision, and adding intellectual content.

\section{Conflicts of interest}

The authors declare that they have no conflict of interest related to the publication of this manuscript.

\section{References}

AHUMADA, J.A., SILVA, C.E.F., GAJAPERSAD, K., HALLAM, C., HURTADO, J., MARTIN, E., MCWILLIAM, A., MUGERWA, B., O'BRIEN, T., ROVERO, F., SHEIL, D., SPIRONELLO, W.R., WINARNI, N. \& ANDELMAN, S.J. 2011. Community structure and diversity of tropical forest mammals: data from a global camera trap network. Phil. Trans. R. Soc. B. 366:2703-2711.

ALVARES, C.A., STAPE, J.L., SENTELHAS, P.C., GONÇALVES, J.L.M. \& SPAROVEK, G. 2014. Köppen's climate classification map for Brazil. Meteorol. Z. 22:711-728.

ALVES, G.B., O. MARÇAL-JUNIOR \& BRITES, V.L.C. 2014. Medium and large-sized mammals of a fragment of Cerrado in the Triângulo Mineiro region, Southeastern Brazil. Biosci. J. 30:863-873. 
ANDERSON, M. 2001. A new method for non-parametric multivariate analysis of variance. Austral Ecol. 26:32-46.

CARDILLO, M., MACE, G.M., JONES, K.E., BIELBY, J., BININDAEMONDS, O.R.P., SECHREST, W., ORME, D.D.L. \& PURVIS, A. 2005. Multiple Causes of High Extinction Risk in Large Mammal Species. Science 309:1239-1241

CARVALHO, F.M.V., DE MARCO JR, P. \& FERREIRA JUNIOR, L.G. 2009. The Cerrado into-pieces: Habitat fragmentation as a function of landscape use in the savannas of central Brazil. Biol. Conserv. 142:1392-1403.

CHIARELLO, A.G.1999. Effects of fragmentation of the Atlantic forest on mammal communities in south-eastern Brazil. Biol. Conserv. 89:71-82.

CLAUDINO, E.S., GOMES, M.A.F. \& CAMPOS, P.R.A. 2015. Extinction debt and the role of static and dynamical fragmentation on biodiversity. Ecol. Complex. 21:150-155.

COUSINS, S.A.O. \& VANHOENACKER, D. 2011. Detection of extinction debt depends on scale and specialization. Biol. Conserv. 144:782-787.

CROOKS, K.R. \& SOULÉ, M.E. 1999. Mesopredator release and avifaunal extinctions in a fragmented system. Nature 400:563-566.

CULLEN JR., L., BODMER, R.E. \& VALLADARES-PÁDUA, C. 2000 Effects of hunting in habitat fragments of the Atlantic forests, Brazil. Biol. Conserv. 95:49-56.

ESTRELA, D.C., D.C. SOUZA, J.M. SOUZA \& CASTRO, A.L.S. 2015. Medium and large-sized mammals in a Cerrado área of the state of Goiás, Brazil. Check List 11: article 1690.

FAHRIG, L. 2003. Effects of habitat fragmentation on biodiversity. Annu. Ver. Ecol. Syst. 34:487-515.

FAHRIG, L. 2013. Rethinking patch size and isolation effects: the habitat amount hypothesis. J. Biogeogr. 40:1649-1663.

LAURANCE, W.F., SAYER, J. \& CASSMAN, K.G. 2014. Agricultural expansion and its impacts on tropical nature. Trends Ecol. Evol. 29:107-116.

FELFILI, J.M. 2003. Fragmentos de florestas estacionais do Brasil Central: diagnóstico e proposta de corredores ecológicos. In Fragmentação florestal e alternativas de desenvolvimento rural na Região Centro-Oeste (R.B. Costa, ed.). Universidade Católica Dom Bosco, Campo Grande, p.195-263.

GIBSON, L., LEE, T.M., KOH, L.P., BROOK, B.W., GARDNER, T.A., BARLOW, J., PERES, C.A., BRADSHAW, C.J.A., LAURANCE, W.F., LOVEJOY, T.E. \& SODHI, N.S. 2011. Primary forests are irreplaceable for sustaining tropical biodiversity. Nature 478:378-381.

IUCN, 2017. The IUCN Red List of Threatened Species, version 2017-3. www. iucnredlist.org (last access in 23/04/2018).

KEINATH, D.A., DOAK, D.F., HODGES, K.E., PRUGH, L.R., FAGAN, W., SEKERCIOGLU, C.H., BUCHART, S.H.M. \& KAUFFMAN, M. 2017. A global analysis of traits predicting species sensitivity to habitat fragmentation. Global Ecol. Biogeogr. 26:115-127.

KLINK, C.A. \& MACHADO, R.B. 2005. A conservação do Cerrado brasileiro. Megadiversidade 1:147-155.

KOLK, J. \& NAAF, T. 2015. Herb layer extinction debt in highly fragmented temperate forests - Completely paid after 160 years? Biol. Conserv. 182:164-172.

KRAUSS, J., BOMMARCO, R., GUARDIOLA, M., HEIKKINEN, R.K., HELM, A., KUUSSAARI, M., LINDBORG, R., OCKINGER, E., PARTEL, M., PINO, J., POYRY, J., RAATIKAINEN, K.M., SANG, A., STEFANESCU, C., TEDER, T. \& ZOBEL, M. 2010. Habitat fragmentation causes immediate and time-delayed biodiversity loss at different trophic levels. Ecol. Lett. 13:597-606.

KUUSSAARI, M., BOMMARCO, R., HEIKKINEN, R.K., HELM, A., KRAUSS, J., LINDBORG, R., OCKINGER, E., PARTEL, M., PINO, J., RODÀ, F., STEFANESCU, C., TEDER, T., ZOBEL, M. \& STEFFANDEWENTER, I. 2009. Extinction debt: a challenge for biodiversity conservation. Trends Ecol. Evol. 24:564-571.

LINDBORG, R. 2007. Evaluating the distribution of plant life-history traits in relation to current and historical landscape configurations. J. Ecol. 95:555-564.
LION, M.B., GARDA, A.A., SANTANA, D.J. \& FONSECA, C.R. 2016. The conservation value of small fragments for Atlantic Forest reptiles. Biotropica 48:265-275.

LYRA-JORGE, M.C., RIBEIRO, M.C., CIOCHETI, G., TAMBOSI, L.R. \& PIVELLO, V.R. 2009. Influence of multi-scale landscape structure on the occurrence of carnivorous mammals in a human-modified savanna, Brazil. Eur. J. Wildlife Res. 53:359-368.

MCGARIGAL, K. \& ENE, E. 2013. FRAGSTATS 4.2: A spatial pattern analysis program for categorical maps. http://www.umass.edu/landeco/research/ fragstats/fragstats.html (last access in 20/02/2015).

METZGER, J.P., MARTENSEN, A.C., DIXO, M., BERNACCI, L.C., RIBEIRO, M.C., TEIXEIRA, A.M.G. \& PARDINI, R. 2009. Time-lag in biological responses to landscape changes in a highly dynamic Atlantic forest region. Biol. Conserv. 142:1166-1177.

MICHALSKI, F. \& PERES, C.A. 2007. Disturbance-mediated mammal persistence and abundance-area relationships in Amazonian forest fragments. Conserv. Biol. 21:1626-1640.

MITTERMEIER, R.A., GIL, P.R., HOFFMAN, M., PILGRIM, J., BROOKS, T., MITTERMEIER, C.G., LAMOREUX, J. \& FONSECA, G.A.B. 2005. Hotspots Revisited: Earth's Biologically Richest and Most Endangered Terrestrial Ecoregions. CEMEX, Mexico City.

MMA - Ministério do Meio Ambiente. 2014. Lista Nacional Oficial de Espécies da Fauna Ameaçadas de Extinção. Portaria MMAn ${ }^{\circ} 444$, de 17 de dezembro de 2014.

MORRIS, W.F., PFISTER, C.A., TULJAPURKAR, S., HARIDAS, C.V., BOGGS, C.L., BOYCE, M.S., BRUNA, E.M., CHURCH, D.R., COULSON, T., DOAK, D.F., FORSYTH, S., GAILLARD, J.M., HORVITZ, C.C., KALISZ, S., KENDALL, B.E., KNIGHT, T.M., LEE, C.T. \& MENGES, E.S. 2008. Longevity can buffer plant and animal populations against changing climatic variability. Ecology 89:19-25.

MYERS, N., MITTERMEIER, R.A., MITTERMEIER, C.G., FONSECA G.A.B. \& KENT, J. 2000. Biodiversity hotspots for conservation priorities. Nature 403:853-858

NORRIS, D., PERES, C.A. \& HINCHSLIFFE, K. 2008. Terrestrial mammal responses to edges in Amazonian forest patches: a study based on track stations. Mammalia 72:15-23.

OKSANEN, J., BLANCHET, F.G., FRIENDLY, M., KINDT, R., LEGENDRE, P., MINCHIN, D., MINCHIN, P.R., O'HARA, R.B., SIMPSON, G.L., SOLYMOS, P., STEVENS, M.H.H., SZOECS, E. \& WAGNER, H. 2017. Vegan: community ecology package. R package version $2.4-4$. https:// CRAN.R-project.org/package $=$ vegan (last access in 04/09/2017)

PAGLIA, A.P., FONSECA, G.A.B., RYLANDS, A.B., HERMANN, G., AGUIAR, L.M.S., CHIARELLO, A.G., LEITE, Y.L.R., COSTA, L.P., SICILIANO, S., KIERULFF, M.C.M., MENDES, S.L., TAVARES, V.C., MITTERMEIER, R.A. \& PATTON, J.L. 2012. Lista anotada dos mamíferos do Brasil. Occasional paper n. 6. Conservation International, Belo Horizonte.

PERES, C.A. 2000. Effects of subsistence hunting on vertebrate community struture in Amazonian Forests. Conserv. Biol. 14:240-253.

PIRES, A.S., FERNANDEZ, F.A.Z. \& BARROS, C.S. 2006. Vivendo em um mundo em pedaços: efeitos da fragmentação florestal sobre comunidades e populações animais. In Biologia da Conservação: essências (C.F.D. Rocha, H.G. Bergallo, M.V. Sluys \& M.A.S. Alves, eds.). Rima Editora, São Carlos, p.231-260.

PRUGH, L.R., STONER, C.J., EPPS, C.W., BEAN, W.T., RIPPLE, W.J., LALIBERTE, A.S. \& BRASHARES, J.S. 2009. The rise of the mesopredator. BioScience 59:779-791.

R DEVELOPMENT CORE TEAM. 2017. R: A Language and Environment for Statistical Computing. Vienna, Austria, R Foundation for Statistical Computing.

RATTER, J.A., RIBEIRO, J.F. \& BRIDGEWATER, S. 1997. The Brazilian Cerrado Vegetation and Threats to its Biodiversity. Ann. Bot. 80:223-230.

REIS, N.R., PERACCHI, A.L., PEDRO, W.A. \& LIMA, I.P. 2006. Mamíferos do Brasil. Universidade Estadual de Londrina, Londrina. 
RIBEIRO, J.F. \& WALTER, B.M.T. 1998. Fitofisionomias do bioma Cerrado. In Cerrado: ambiente e flora (S.M. Sano \& S.P. Almeida, eds.). Embrapa, Planaltina, p.89-166.

RODRIGUES, F.H.G., SILVEIRA, L., JÁCOMO, A.T.A., CAMIGNOTTO, A.P., BEZERRA, A.M.R., COELHO, D.C., GARBOGINI, H., PAGNOZZI, J. \& HASS, A. 2002. Composição e caracterização da fauna de mamíferos do Parque Nacional das Emas, Goiás, Brasil. Rev. Bras. Zool. 19:589-600.

ROCHA, E.C., SOARES, K.L. \& PEREIRA, I.M. 2015. Medium-and largesized mammals in Mata Atlântica State Park, southeastern Goiás, Brazil. Check List 11:1-7.

SANO, E.E., ROSA, R., BRITO, J.L. \& FERREIRA JR, L.G. 2007. Mapeamento de cobertura vegetal do bioma Cerrado: estratégias e resultados. Documentos 190, Embrapa Cerrados, Planaltina.
SANTOS-FILHO, M., PERES, C.A., SILVA, D.J. \& SANAIOTTI, T.M. 2012. Habitat patch and matrix effects on small-mammal persistence in Amazonian Forest fragments. Biodivers. Conserv. 21:1127-1147.

SEMPER-PASCUAL, A., MACCHI, L., SABATINI, F.M., DECARRE, J., BAUMANN, M., BLENDINGER, R.G., GÓMEZ-VALENCIA, B., MASTRANGELO, M.E. E KUEMMERLE, T. 2018. Mapping extinction debt highlights conservation opportunities for birds and mammals in the South American Chaco. J. Appl. Ecol. 55:1-12.

UEZU, A., METZGER, J. \& VIELLIARD, J. 2005. Effects of structural and functional connectivity and patch size on the abundance of seven Atlantic Forest bird species. Biol. Conserv. 123:507-519.

WOLFF, J.O., SCHAUBER, E.M. \& EDGE, W.D. 1997. Effects of habitat loss and fragmentation on the behavior and demography of Gray-tailed voles. Conserv. Biol. 11:945-956. 